\title{
Designing a comprehensive model of organizational resilience in the banking industry of Iran
}

\author{
Mahmood Khajehpour \\ Shahid Beheshti University, Tehran, Iran \\ Eldar Sedaghatparast \\ Iran Banking Institute, Tehran, Iran, and \\ Masood Rabieh \\ Shahid Beheshti University, Tehran, Iran
}

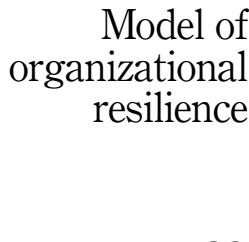

69

Received 26 January 2021

Revised 11 April 2021 28 May 2021

26 September 2021

Accepted 27 September 2021

\begin{abstract}
Purpose - This research aims to design a comprehensive resilience model in the banking industry for identifying the dimensions and components that can enhance organizational resilience in the industry, which can contribute to the existing literate as a promising comprehensive model.

Design/methodology/approach - After reviewing the literature and studying the models of organizational resilience, semistructured interviews were conducted with managers and prominent experts in the banking industry. To analyze the interviews, the thematic analysis technique was used with three coding stages. After designing the research model in two main dimensions of micro and macro management in the banking industry, the relation between the main components and subcomponents was identified by using Interpretive Structural Modeling (ISM) and DEMATEL techniques.

Findings - The study findings indicating that proper observation and predicting the bank's problems and making suitable connections with the government are two major indicators of the resilience of the banking network, which can realize through influencing the components of risk management, financial resource management and system corruption. The results of this research can lead to the expansion of theoretical foundations of the past research and the concept of organizational resilience in the field of financial services and especially the banking industry.

Originality/value - This paper provides the components with a more significant impact, which bank managers should consider the relationship among them to enhance organizational resilience for more effectiveness of their decisions.
\end{abstract}

Keywords Organizational resilience, DEMATEL, Mixed research methodology, Banking industry, Interpretative structural modeling

Paper type Research paper

\section{Introduction}

In recent years, globalization and rapid economic growth caused many crises in the banking sector, which can influence the risk of bankruptcy of many businesses associated with the banking system across the world (Ismal, 2012; Buzgurescu and Elena, 2020). Comprehensive and exact decisions are required to manage these chaotic circumstances with highly uncertainly. Besides, the chaotic result of these decisions can add enormous uncertainties to the situation (Berglund and Makinen, 2019; Omar, 2008). In such high-risk situations, each

(C) Mahmood Khajehpour, Eldar Sedaghatparast and Masood Rabieh. Published in Asian Journal of Economics and Banking. Published by Emerald Publishing Limited. This article is published under the Creative Commons Attribution (CC BY 4.0) licence. Anyone may reproduce, distribute, translate and create derivative works of this article (for both commercial and non-commercial purposes), subject to full attribution to the original publication and authors. The full terms of this licence may be seen at http:// creativecommons.org/licences/by/4.0/legalcode

Funding: The authors declare that there is no competing financial interest.

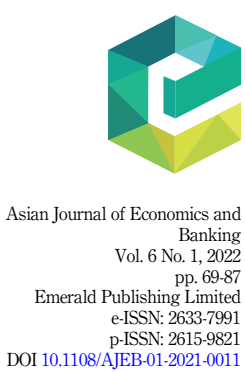


AJEB

6,1 firm and organization must try to maintain their balance and survival with the least negative impact of these situations. Failure to maintain balance and equivalence in the conditions of the firm and organization may lead to the collapse of stock values, jeopardizing their interests and even bankruptcy (Naqvi et al., 2018).

Banks as financial intermediaries play the role of providing financial needs for manufacturing and commercial units. Banks should be able to absorb small capital on one side and, on the other side, provide services to industrial and manufacturing units to strengthen them, and as a result, manufacturing units can properly play their role in the national economy. The occurrence of a crisis in this sector might jeopardize financial stability (Field, 2017; Kim et al., 2020).

Organizational resilience can be considered to keep balance and equivalence not only in the banking system but also in all the related organizations to the banking system. However, the lack of study of organizational resilience in the banking industry can lead to stagnation and even bankruptcy crises in the banks (Prorokowski, 2011). This crisis can have devastating effects on the economy due to the interdependency of the state economy and banks (Costa and Carini, 2016).

Identifying the dimensions and components of organizational resilience can enable managers to identify the key points, dimensions and components of resilience to increase it in their organization and set up a coherent and consistent design and plan to improve the banking environment to deal with crises and unpredictable events (Anagnostopoulos et al., 2020). The lack of a comprehensive and native model in this regard makes the issue of bank resilience unsolved until the happening crisis. Instead of preventing the possibility of unlikely damages in the banking services process by using a resilient organization design, the manager waits for the finalization of damages on the banking system and then plans for suitable action to solve these damages (Pineiro-Chousa et al., 2019). This attitude will not be effective without introducing a comprehensive model for high-level executives. Also, the risk and damage may reduce the ability of the bank in providing some services and consequently reduce the number of customers (Bravo et al., 2016).

The present study seeks to identify the dimensions and components of organizational resilience in the banking industry. Then, by using one of the soft approaches in the operations research, which is called Interpretive Structural Modeling (ISM) (Satapathy et al., 2012), the relationships between the components and a structural-interpretative model were presented.

Finally, to provide a clearer insight of the cause-and-effect relationship between the components of the resiliency and determining their significance, one of the multiattribute decision-making techniques (Lu et al., 2015), entitled DEMATEL (Yüksel et al., 2017), should be used to analyze the relations between subcomponents.

This research contributes to the existing literature via the following scientific outcomes: Firstly, this research expands the theoretical foundations of the previous research studies and the concept of organizational resilience in the field of financial services and especially in the banking industry. It is important to note that the extension of this concept is based on both theoretical research and the opinion of the experts working in the banking industry. Secondly, the proposed model could help managers to have a better and more comprehensive understanding of their organization and potential disruptions affecting the identified components of resilience. Thirdly, the results of this study can help managers to enhance the organization's resistance and resilience in the face of unforeseen disturbances.

\section{Literature review}

\subsection{Resilience}

Resilience is a concept that is used in various scientific fields and disciplines and in general indicates that every system must enhance its capabilities against disturbing events such as 
internal and external deviations, changes and disturbances (Sahebjamnia et al., 2018). In other words, resilience is defined as the ability of a system to recover and return to its original state or moving to a new and more favorable state after a disturbance (Rose, 2017). A resilience system not only shows endurance in occurring of crises but also can return the system to its state in the shortest possible time with high flexibility (Dormady et al., 2019). Organizational resilience is a new and growing concept in literature and management research that focuses on maintaining organizational life in rapid changes and unforeseen impairments (Andersson et al., 2019). Management researchers used organizational resilience as an organization's ability to deal with disturbances to maintain organizational configurations or create new organizational configurations that have more appropriateness with the upcoming conditions (McCarthy et al., 2017).

Banks as financial intermediaries play an important role in providing financial needs for manufacturing and commercial sectors. Because of the critical role of this industry in production, consumption, investment and other variables and institutions, providing a healthy and resilient banking system is very important to deal with shocks and managing economies (Shahoseini et al., 2014).

\subsection{Resilience in the banking industry}

The issue of resilience of the banking system should be considered in the context of the whole system of governing the banking system, including the central bank, commercial and specialized banks and the economy of Iran, in which the type of interaction of banking system with the economy is considered according to the banking rules and regulations of Iran.

However, from a different perspective, in the case of banks, we can ask what is resilience in the banking system? Based on surveys, it is clear that a resilient bank can withstand shocks. These banks can gain the trust of depositors and investors, so they can even receive funds during periods of tension (Fiksel, 2006). This is the main reason that the adequacy of the capital ratio is considered as one of the main indicators of the resilience of the banking system.

\section{Previous research}

Ratnovski and Huang (2009) explored why Canadian banks are more resilient than banks in OECD countries. They stressed three criteria in resilience, including the ratio of capital, liquidity and fund structure. Dovern et al. (2010) highlighted the resilience of the German banking system in macroeconomic shocks. In this paper, a collection of bank profit and loss data over 39 years was used for modeling. Furthermore, the used method was vector autoregression (VAR). In a study by Markman and Venzin (2014), researchers studied the resilience and stamina of banks during financial and nonfinancial crises, as well as the performance of banks that could not resist these crises. Their findings showed that resilience is conceptualized as a firm's ability to adapt, endure, bounce back and then thrive despite a catastrophic event, which can help increase awareness about firms' long-term financial performance. Also, the VOLARE can determine the long-term endurance of a bank. Annarelli and Nonino (2016) performed a systematic review to generate a model of organizational resilience for understanding its components in strategic and operational management.

Kantur and Iseri-Say (2015) studied both qualitative and quantitative methods to improve the definition of organizational resilience. In this paper, Multitrait-Multimethod Matrix (MTMM) was developed to validate the defined structure of resilience. Their findings showed that organizational resilience is formed from three distinct aspects including robustness, agility and integrity. In another study, Farooq and Zaheer (2015) examined the resilience of Islamic banks in financial crises. The results showed that the Islamic branches of banks that have both Islamic and non-Islamic operations tend to attract deposits (instead of decreasing them), which indicates the role of the religious brand. Resultantly, financial durability may be 
AJEB

6,1

\section{2}

increased by the religion-inspired or contrarily altruistic purposes continued by a set of bank directors and/or their customers.

Alrob and Jaaron (2018), in their research, examined the Palestinian banking system and provided indicators to increase its resilience. Semistructured interviews, observations and archival documents were used to collect data, which was integrated by using the Resilience Benchmark Tool (RBT). Their findings showed that the two Islamic banks included in the study possess relatively high levels of resilience capabilities.

Berglund and Makinen (2019) identified whether banks are learning from the financial crisis by studying the experience of Nordic banks. They used a large panel of Scandinavian countries, including Finland, Norway and Sweden, and European banks for the period of 1994-2010. The key findings of the researchers are that, after controlling banking features and macroeconomic factors, Nordic banks have had more returns and more financial stability than other European banks during the 2008 crisis. During the 2008 crisis, the entire Danish banking sector experienced severe difficulties, mostly because of a real-estate collapse cycle fueled by excessive lending. As a result, several banks needed broad financial support from the Danish government to continue their business.

Recently, Duchek (2020) shed a light on very heterogeneous literature in organizational resilience. In this research, resilience was defined as a meta-capability and disintegrated to their components and relationships between them. Also, three stages of progressive organizational resilience performance were determined to explain it successively. Their conceptualization showed that little information exists on resilience capabilities in organization and management studies, but the research in other disciplines (e.g. psychology, ecology and resilience engineering) is very insightful. In Table 1, briefly, some previous studies have been reviewed. Approaches used in various papers show that all presented models are not comprehensive and do not include financial, regulatory,

\begin{tabular}{|c|c|c|c|}
\hline Researcher/year & Subject & Country & Indexes \\
\hline $\begin{array}{l}\text { Ratnovski and } \\
\text { Huang (2009) }\end{array}$ & $\begin{array}{l}\text { Reviewing the resilience of } \\
\text { Canadian banks to OECD banks }\end{array}$ & Canada & $\begin{array}{l}\text { The ratio of capital, liquidity and } \\
\text { structure of funds }\end{array}$ \\
\hline $\begin{array}{l}\text { Dovern et al. } \\
(2010)\end{array}$ & $\begin{array}{l}\text { The resilience of the German } \\
\text { banking system to } \\
\text { macroeconomic shocks }\end{array}$ & German & $\begin{array}{l}\text { The bank's profit and loss data over } \\
39 \text { years has been used for modeling }\end{array}$ \\
\hline $\begin{array}{l}\text { Boorman et al. } \\
\text { (2013) }\end{array}$ & Resilience index of countries & - & $\begin{array}{l}\text { Asset quality, the ratio of capital base, } \\
\text { proportion of equity to the property } \\
\text { Nonoperating loans to total bank loans }\end{array}$ \\
\hline $\begin{array}{l}\text { Markman and } \\
\text { Venzin (2014) }\end{array}$ & $\begin{array}{l}\text { The resilience and stamina of the } \\
\text { banks during the crisis }\end{array}$ & - & $\begin{array}{l}\text { Financial indicators such as the ratio of } \\
\text { return on investment, and shareholder } \\
\text { return, tax, depreciation, economic value- } \\
\text { added, balanced scorecard }\end{array}$ \\
\hline $\begin{array}{l}\text { Farooq and } \\
\text { Zaheer (2015) }\end{array}$ & $\begin{array}{l}\text { Comparison of Islamic and non- } \\
\text { Islamic banks' resilience in } \\
\text { dealing with crises }\end{array}$ & Pakistan & $\begin{array}{l}\text { The role of the religious brand in } \\
\text { resilience }\end{array}$ \\
\hline $\begin{array}{l}\text { Alrob and } \\
\text { Jaaron (2018) }\end{array}$ & $\begin{array}{l}\text { Provide indicators for increasing } \\
\text { resilience in Islamic banks }\end{array}$ & Palestine & $\begin{array}{l}\text { Adaptive capabilities, programming } \\
\text { capabilities }\end{array}$ \\
\hline Selmier (2016) & $\begin{array}{l}\text { Design rules for more resilient } \\
\text { banking systems }\end{array}$ & $\begin{array}{l}\text { Australia, Brazil, } \\
\text { Canada and } \\
\text { China }\end{array}$ & $\begin{array}{l}\text { Incentive structure, nature of financial } \\
\text { networks, the involvement of all agents in } \\
\text { the financial market, adaptive agents, the } \\
\text { complexity of boundaries }\end{array}$ \\
\hline $\begin{array}{l}\text { Berglund and } \\
\text { Mäkinen (2019) }\end{array}$ & $\begin{array}{l}\text { Experience of Nordic banks in } \\
\text { resilience }\end{array}$ & - & Financial Indices between 1994 and 2010 \\
\hline Fiksel (2006) & $\begin{array}{l}\text { Factors affecting capital in } \\
\text { banking industry with resilience } \\
\text { approach }\end{array}$ & - & $\begin{array}{l}\text { Capital as a proxy for resilience in the } \\
\text { banking industry }\end{array}$ \\
\hline
\end{tabular}

Table 1.

Summary of some previous research 
governmental, organizational structures and so forth. In the present study, a collection of resilience indicators based on identified cases and expert opinions were used. On the other hand, the review of various studies showed that other researchers have not considered other factors such as sanctions or exchange rate fluctuations, which caused disturbances in banking systems due to the different conditions in the studied countries. Therefore, there is a research gap in terms of extracting the indicators of practical impact on organizational resilience of banks, which the researcher attempts to reduce this existing gap.

\section{Model of organizational resilience}

\section{Methodology}

This research is based on a mixed approach, which is considered as relevant and developmental research in terms of its goal and outcome, respectively, since it intended to design a resilience model in the banking industry. As the present research is mixed, the methodology of the research should be presented separately from the qualitative as well as quantitative sections. So, the objectives of this research are categorized into qualitative and quantitative. Qualitative ones are followed using a deep literature review and questionnaire methods. Quantitative ones were followed using by using the ISM method and DEMATEL method. The population of the study was experts and managers of the banking industry. The samples were selected using a snowball sampling method. Figure 1 shows the research graph design of our methodology in the current study.

In this study, library studies and semistructured interviews were used to collect data. Ten interviews with some experts in the banking sector were done to reach data saturation, and two subsequent interviews were done later. Each interview lasted for $1-3 \mathrm{~h}$. The data analysis method was thematic analysis. This method is used for determining, analyzing and expressing the themes of the data. This method, at least, organizes the data and describes it in detail. However, it can go further and interpret various aspects of the subject of the research (Braun et al., 2014).

In this method, the data are first encoded, and then the underlying concepts are extracted from them. Then, the main categories are created from the concepts; and the final model is designed based on the classification. The retest reliability method and the intrasubject agreement method were used to measure the reliability of the interviews. If this is more than $60 \%$, it is a sign of the reliability of the interviews (Syahkali Moradi, 2018).

To determine the reliability of the retest, two interviews were selected from the encoded interviews and re-encoded after one week. The retest agreement was calculated at around $95 \%$. Also, to evaluate the intrasubject agreement, the results of the topic analysis were asked from two collaborative researchers to encrypt two separate interviews. The agreement of the internally coding of the researcher and collaborative researchers was 75 and $79 \%$, respectively, indicating the reliability of the results (Table 2).

In the second and quantitative part of the research, questionnaires based on the identified and confirmed components of the interviews by the experts were used and the comments of ten specialists and experts who took part in the first phase of the study and we had access to them were gathered. Then, the relationships between the components were determined by using the ISM method for the main components and the DEMATEL method for subcomponents. This method is used when we intend to use coherent and systematic thinking about a complex subject (Olfat and Shahriyarinia, 2014). In Table 3, the goals, data collection tools and data analysis methods are presented in two qualitative and quantitative research sections.

\section{Findings}

In this part, the findings of the research are presented in two parts. In the first section, the findings from the thematic analysis of expert interviews are presented. In the second part, the 


\section{AJEB \\ 6,1}

Figure 1.

The research graph design

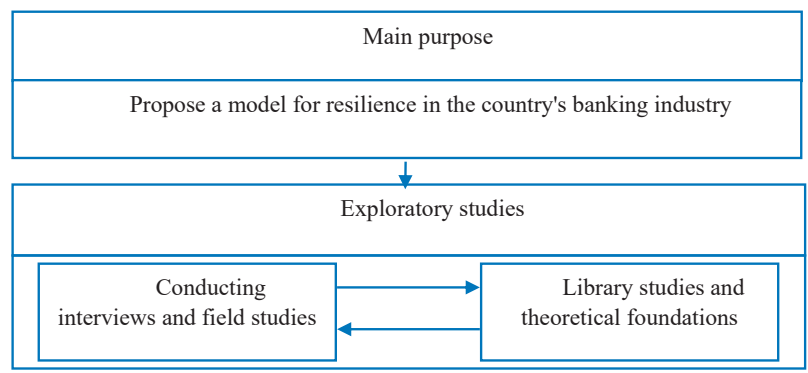

Qualitative analysis based on thematic analysis and design and development of the initial model

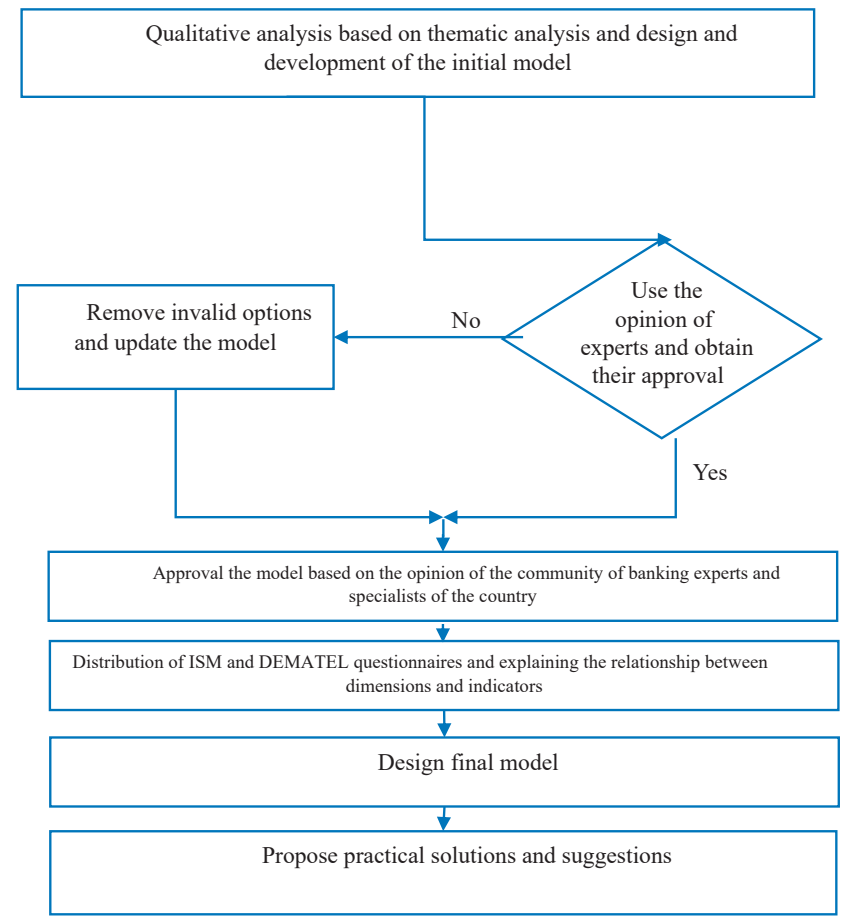

results of ISM on the model extracted from the thematic analysis and the use of quantitative technique DEMATEL to identify the relation and impact of the components of the model expressed.

\subsection{Qualitative findings}

After multiple reviews of the model by the first-level attending experts, finally, after eliminating the out-of-scope suggestions and adjusting duplicate components with two or more names, 18 concepts, 11 subcategories and 2 main categories were obtained in the form of the model shown in Figure 2.

After extracting the model, the structure of the relationship between dimensions and components was investigated using the ISM structuring technique and DEMATEL technique to determine the relationships and their intensity and power. 
Education

Work experience (years)

1. Ph.D. in financial management

2. Ph.D. in economics

3. Ph.D. in economics

4. Ph.D. in economics

5. Ph.D. in accounting

6. Ph.D. in IT management

7. Ph.D. in management

$8 \mathrm{Ph} . \mathrm{D}$. in financial management

9. Ph.D. in management

10. Ph.D. in financial management

11. Ph.D. in management

12. Ph.D. in management

20
10
10
10
10
10
10
20
16
20
11
12

Model of

Age (year)

50

45

41

40

42

40

44

53

43

51

31

46 organizational

resilience

75

Table 2.

Demographic

characteristics of interviewees

\begin{tabular}{|c|c|c|c|c|}
\hline Step & $\begin{array}{l}\text { Data analysis } \\
\text { method }\end{array}$ & Data collection tools & Research goal & \\
\hline 1 & Thematic analysis & $\begin{array}{l}\text { Library research and } \\
\text { interview }\end{array}$ & $\begin{array}{l}\text { Identifying dimensions and components of } \\
\text { banking resilience model }\end{array}$ & $\begin{array}{r}\text { Table } 3 . \\
\text { Data collection tools } \\
\text { and analysis methods }\end{array}$ \\
\hline 2 & $\begin{array}{l}\text { ISM and DEMATEL } \\
\text { techniques }\end{array}$ & $\begin{array}{l}\text { ISM and DEMATEL } \\
\text { questionnaires }\end{array}$ & $\begin{array}{l}\text { Determining the relationship between components } \\
\text { of the resilience model of the banking industry }\end{array}$ & $\begin{array}{l}\text { appropriate to each } \\
\text { step of the research }\end{array}$ \\
\hline
\end{tabular}

\subsection{Quantitative findings}

5.2.1 Principal component analysis relationships with ISM. The ISM approach suggests the use of expert opinions, using some management techniques such as brainstorming or nominal group techniques, to develop the contextual relationships among the variables. A questionnaire was designed to organize the identified factors. Each of the experts was asked to compare the components in parallel.

If the component of the row is the prerequisite component of the column component, this relationship is represented by $\mathrm{V}$. If the component of the column is the prerequisite of the row component, this relationship is represented by A; if both components need each other, this relationship is shown by $\mathrm{X}$, and $\mathrm{O}$ is the representation of lack of need. Specialists, according to their knowledge and experience, have identified the relationship between organizational resilience components in banks (Table 4).

The Initial Reachability Matrix acts by replacing the icons in the SSIM matrix with 0 and 1 according to the following rules: If the sign $\mathrm{V}$ stands in the house $(i, j)$, then the value of that house is equal to 1 , and the value of the mirror house is 0 ; If the sign A stands in the house, then the value of that house is 0 , and the value of the mirror house is equal to 1 ; If the sign $\mathrm{X}$ stands in the house, then the value of that house and the value of the mirror house is equal to 1 ; If the sign O stands in the house, then the value of that house and the value of the mirror house will be 0 . More details are listed in Table 5 .

Once the Initial Reachability Matrix has been achieved, its internal consistency should be established. For example, if variable 1 leads to variable 2 , and variable 2 also lead to variable 3 , variable 1 must also result in variable 3 . If it does not exist in the access matrix, then the modified matrix and the relationships that have been eliminated should be corrected and replaced. In the goal matrix, the corrections are shown with $1^{*}$. This relationship was calculated for all the factors individually and corrected wherever needed, manually. In this way, the Final Reachability Matrix is plotted in Table 6. 


\section{AJEB}

6,1

76

Figure 2.

Main and

subcomponents of the resilience model in the bank

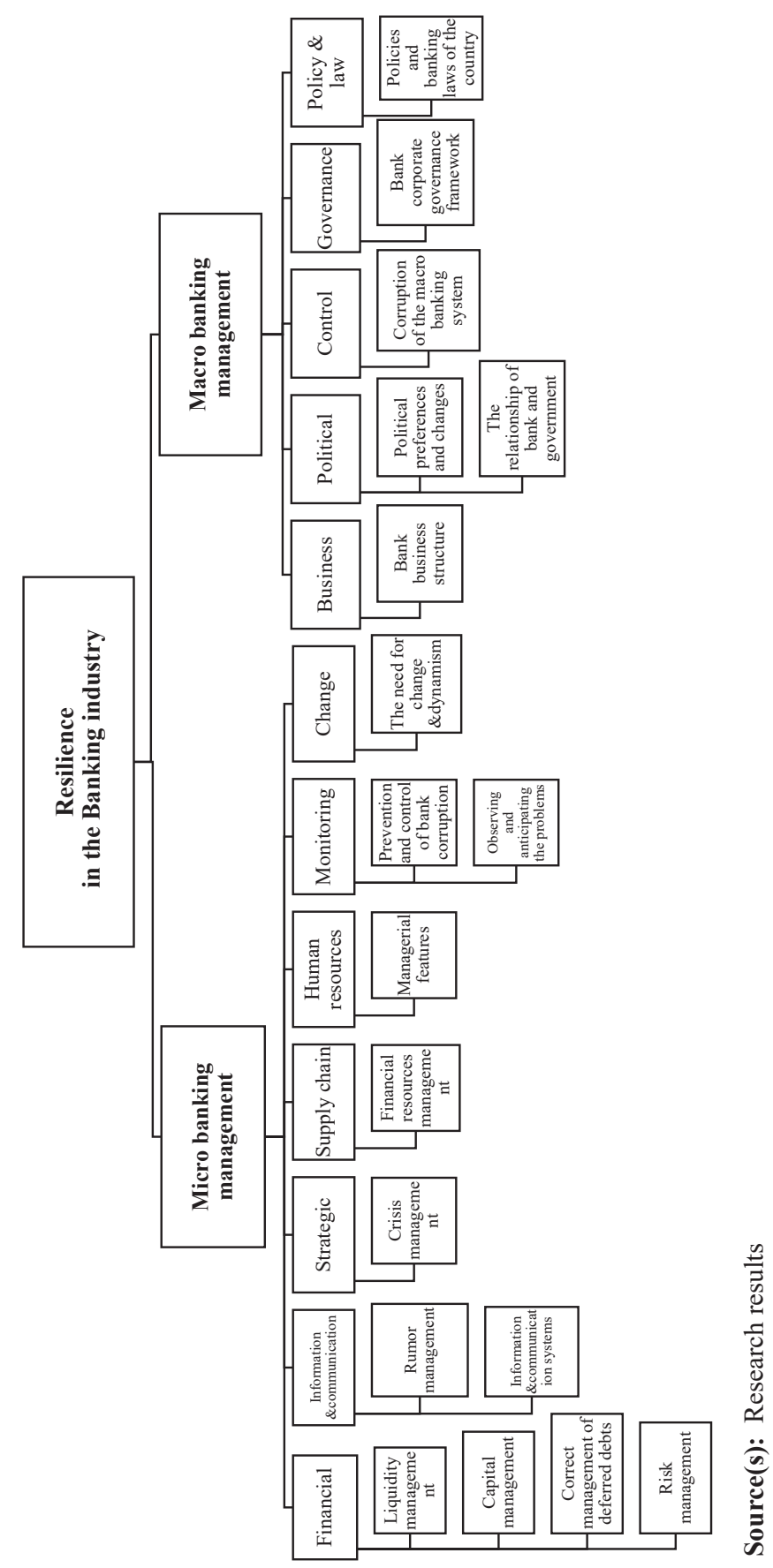


Components

1. Financial

2. Information and communication

3. Strategic

4. Supply chain

5. Human resources

6. Monitoring

7. Change

8. Business

9. Political

10. Control

11. Governance

12. Policy and law

Source(s): Research results
Model of organizational resilience

$\begin{array}{lllllllllll}\text { A } & \text { A } & \text { A } & \text { A } & \text { A } & \text { A } & \text { A } & \text { A } & \text { A } & \text { X } & \text { A }\end{array}$

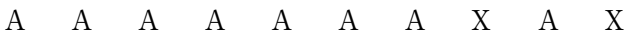

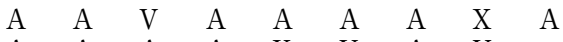

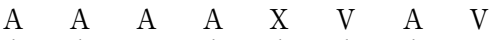

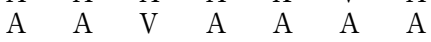

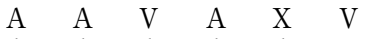

A $A \quad$ A $A$ A

A A A A

$\begin{array}{lll}\mathrm{V} & \mathrm{X} & \mathrm{V}\end{array}$

A A

V

Table 4

Structural self-

interaction

matrix (SSIM)

\begin{tabular}{lcccccccccccc} 
Components & 1 & 2 & 3 & 4 & 5 & 6 & 7 & 8 & 9 & 10 & 11 & 12 \\
\hline 1. Financial & 1 & 0 & 1 & 0 & 0 & 0 & 0 & 0 & 0 & 0 & 0 & 0 \\
2. Information and communication & 1 & 1 & 1 & 0 & 1 & 0 & 0 & 0 & 0 & 0 & 0 & 0 \\
3. Strategic & 1 & 1 & 1 & 0 & 1 & 0 & 0 & 0 & 0 & 1 & 0 & 0 \\
4. Supply chain & 1 & 1 & 1 & 1 & 1 & 0 & 1 & 1 & 0 & 0 & 0 & 0 \\
5. Human resources & 1 & 1 & 1 & 0 & 1 & 0 & 0 & 0 & 0 & 1 & 0 & 0 \\
6. Monitoring & 1 & 1 & 1 & 1 & 1 & 1 & 1 & 1 & 0 & 1 & 0 & 0 \\
7. Change & 1 & 1 & 1 & 0 & 1 & 0 & 1 & 0 & 0 & 0 & 0 & 0 \\
8. Business & 1 & 1 & 1 & 1 & 1 & 1 & 1 & 1 & 0 & 0 & 0 & 0 \\
9. Political & 1 & 1 & 1 & 1 & 1 & 1 & 1 & 1 & 1 & 1 & 1 & 1 \\
10. Control & 1 & 1 & 0 & 1 & 0 & 0 & 1 & 1 & 0 & 1 & 0 & 0 \\
11. Governance & 1 & 1 & 1 & 1 & 1 & 1 & 1 & 1 & 1 & 1 & 1 & 1 \\
12. Policy and law & 1 & 1 & 1 & 1 & 1 & 1 & 1 & 1 & 0 & 1 & 0 & 1
\end{tabular}

Table 5.

Initial reachability matrix

\begin{tabular}{|c|c|c|c|c|c|c|c|c|c|c|c|c|}
\hline Components & 1 & 2 & 3 & 4 & 5 & 6 & 7 & 8 & 9 & 10 & 11 & \\
\hline 1. Financial & 1 & $1 *$ & 1 & 0 & $1^{*}$ & 0 & 0 & 0 & 0 & $1 *$ & 0 & \\
\hline 2. Information and communication & 1 & 1 & 1 & 0 & 1 & 0 & 0 & 0 & 0 & $1^{*}$ & 0 & \\
\hline 3. Strategic & 1 & 1 & 1 & $1 *$ & 1 & 0 & $1^{*}$ & $1^{*}$ & 0 & 1 & 0 & \\
\hline 4. Supply chain & 1 & 1 & 1 & 1 & 1 & $1 *$ & 1 & 1 & 0 & $1 *$ & 0 & \\
\hline 5. Human resources & 1 & 1 & 1 & $1 *$ & 1 & 0 & 0 & 0 & 0 & 1 & 0 & \\
\hline 6. Monitoring & 1 & 1 & 1 & 1 & 1 & 1 & 1 & 1 & 0 & 1 & 0 & \\
\hline 7. Change & 1 & 1 & 1 & 0 & 1 & 0 & 1 & 0 & 0 & 0 & 0 & \\
\hline 8. Business & 1 & 1 & 1 & 1 & 1 & 1 & 1 & 1 & 0 & $1^{*}$ & 0 & \\
\hline 9. Political & 1 & 1 & 1 & 1 & 1 & 1 & 1 & 1 & 1 & 1 & 1 & \\
\hline 10. Control & 1 & 1 & $1 *$ & 1 & $1^{*}$ & $1 *$ & 1 & 1 & 0 & 1 & 0 & Table 6. \\
\hline 11. Governance & 1 & 1 & 1 & 1 & 1 & 1 & 1 & 1 & 1 & 1 & 1 & Final reachability \\
\hline 12. Policy and law & 1 & 1 & 1 & 1 & 1 & 1 & 1 & 1 & 0 & 1 & 0 & matrix \\
\hline
\end{tabular}

After calculating the Final Reachability Matrix, the model levels must be specified. So, the set of inputs and outputs of each of the components is determined, and if the outputs and the computed aggregate are the same, then that component is related to the same level. 
AJEB

6,1

\section{8}

Table 7.

Determining the first-

level components

To calculate the outputs, the houses listed in the first row are numbered 1 . If all of the components were related to the same level, it is a one-level model; otherwise, we should go to the next level.

On the next level, their components and numbers are deleted. For example, if the first component is related to level 1 , then that component is removed at the next step, and number 1 is deleted from the input and output sets. The results of the components leveling are presented in Table 7.

According to the results, it is clear that components 9 and 11, that is, the governance and political components of the first level, are effective, and by eliminating these components, the allocation of other components will continue to the next levels.

To specify the components of the next system, the leveling components are removed from Table 7, and Table 8 is formed with the remaining components, and this will continue until all components are determined. The results are shown in Table 8.

Based on the results, the six-level model was designed according to Figure 3. In this diagram, the primary 12 components of the model are ranked from top to down, respectively. The components of the highest level of the model include the components of political and government relations, represent the first and underlying level of the model. Factors that are at higher levels are less effective and more affected by the lower-level factors.

5.2.2 MICMAC analytical chart. The purpose of MICMAC analysis is to identify and analyze the power of influence and the dependency of the main components. The influence

\begin{tabular}{|c|c|c|c|c|}
\hline & Affected by & Effect on & Intersection set & Level \\
\hline$C_{1}$ & 1.2.3.4.5.6.7.8.9.10.11.12 & 1.2.3.5.10 & 1.2 .3 .5 .10 & \\
\hline $\mathrm{C}_{2}$ & 1.2.3.4.5.6.7.8.9.10.11.12 & 1.2.3.5.10 & 1.2.3.5.10 & \\
\hline$C_{3}$ & 1.2.3.4.5.6.7.8.9.10.11.12 & 1.2.3.4.5.7.8.10 & 1.2.3.4.5.7.8.10 & \\
\hline$C_{4}$ & 3.4.5.6.8.9.10.11.12 & 1.2.3.4.5.6.7.8.10 & 3.4.5.6.7.10 & \\
\hline$C_{5}$ & 1.2.3.4.5.6.7.8.9.10.11.12 & 1.2.3.4.5.10 & 1.2.3.4.5.10 & \\
\hline$C_{6}$ & 4.6.8.9.10.11.12 & 1.2.3.4.5.6.7.8.10 & 4.6.8.10 & \\
\hline$C_{7}$ & 3.4.6.7.8.9.10.11.12 & 1.2.3.5.7 & 3.7 & \\
\hline$C_{8}$ & 3.4.6.8.9.10.11.12 & 1.2.3.4.5.6.7.8.10 & 3.4 .8 .10 & \\
\hline$C_{9}$ & 9.11 & 1.2.3.4.5.6.7.8.9.10.11.12 & 9.11 & 1 \\
\hline$C_{10}$ & 1.2.3.4.5.6.8.9.10.11.12 & 1.2.3.4.5.6.7.8.10 & 1.2.3.4.5.6.8.10 & \\
\hline$C_{11}$ & 9.11 & 1.2.3.4.5.6.7.8.9.10.11.12 & 9.11 & 1 \\
\hline$C_{12}$ & 9.11 .12 & 1.2.3.4.5.6.7.8.10.12 & 12 & \\
\hline
\end{tabular}

Table 8.

Components leveling (combining repetitions from the second to the fourth)

\begin{tabular}{lllll}
\hline & \multicolumn{1}{c}{ Affected by } & \multicolumn{1}{c}{ Effect on } & Intersection set & Level \\
\hline$C_{1}$ & 1.2 .3 .4 .5 .6 .7 .8 .9 .10 .11 .12 & 1.2 .3 .5 .10 & 1.2 .3 .5 .10 & 6 \\
$C_{2}$ & 1.2 .3 .4 .5 .6 .7 .8 .9 .10 .11 .12 & 1.2 .3 .5 .10 & 1.2 .3 .5 .10 & 6 \\
$C_{3}$ & 1.2 .3 .4 .5 .6 .7 .8 .9 .10 .11 .12 & 1.2 .3 .4 .5 .7 .8 .10 & 1.2 .3 .4 .5 .7 .8 .10 & 4 \\
$C_{4}$ & 3.4 .5 .6 .8 .9 .10 .11 .12 & 1.2 .3 .4 .5 .6 .7 .8 .10 & 3.4 .5 .6 .7 .10 & 4 \\
$C_{5}$ & 1.2 .3 .4 .5 .6 .7 .8 .9 .10 .11 .12 & 1.2 .3 .4 .5 .10 & 1.2 .3 .4 .5 .10 & 6 \\
$C_{6}$ & 4.6 .8 .9 .10 .11 .12 & 1.2 .3 .4 .5 .6 .7 .8 .10 & 4.6 .8 .10 & 3 \\
$C_{7}$ & 3.4 .6 .7 .8 .9 .10 .11 .12 & 1.2 .3 .5 .7 & 3.7 & 7 \\
$C_{8}$ & 3.4 .6 .8 .9 .10 .11 .12 & 1.2 .3 .4 .5 .6 .7 .8 .10 & 3.4 .8 .10 & 4 \\
$C_{9}$ & 9.11 & 1.2 .3 .4 .5 .6 .7 .8 .9 .10 .11 .12 & 9.11 & 1 \\
$C_{10}$ & 1.2 .3 .4 .5 .6 .8 .9 .10 .11 .12 & 1.2 .3 .4 .5 .6 .7 .8 .10 & 1.2 .3 .4 .5 .6 .8 .10 & 3 \\
$C_{11}$ & 9.11 & 1.2 .3 .4 .5 .6 .7 .8 .9 .10 .11 .12 & 9.11 & 1 \\
$C_{12}$ & 9.11 .12 & 1.2 .3 .4 .5 .6 .7 .8 .10 .12 & 12 & 2 \\
\hline
\end{tabular}



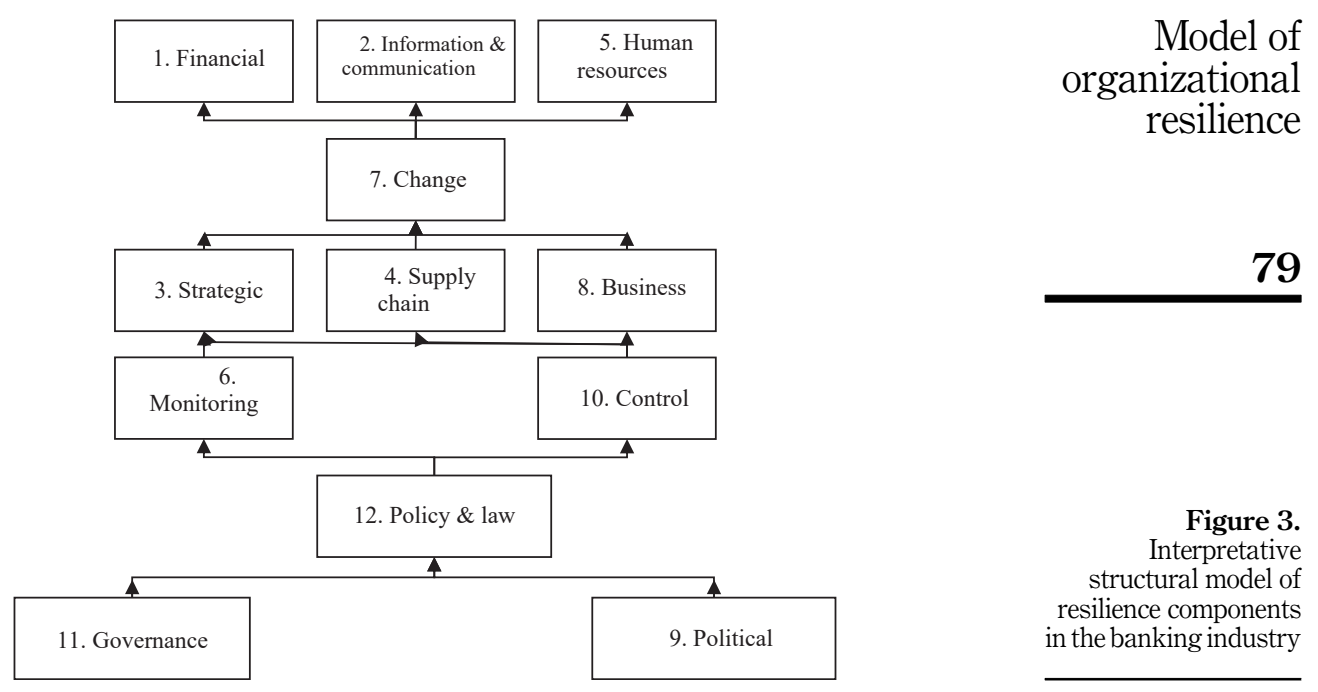

and dependency of each factor are expressed as points in the coordinate space by using the results of calculations of the goals achievement matrix. After the determination of the relationship between the components, the infiltration-dependency diagram is depicted in Figure 4.

Based on the results, the level of the effectiveness of each component and their categorization were determined in the quad graph regions. Accordingly, bank managers should first focus on the components that are at the highest levels of the model to increase organizational resilience in the banking industry. Also, these components must be in the independent (Driver) and Linkage parts of the diagram in Figure 4. Improving the components located in these two areas can make the other components more effective.

5.2.3 Investigation of the magnitude and severity of the effects of banking management components. The DEMETL technique was used to investigate the relationship between banking subcomponents at micro and macro levels. After collecting the questionnaires, the average opinions of the experts were collected and placed in the computational model. The results of the calculations are presented in Table 9. $(D)$ is calculated as the sum of rows, and the sum of columns is defined by $(R)$. According to the $D$ and $R$ values, $R+D$ and $R-D$ can be calculated. Eqs. (1) and (2) for calculation of $D$ and $R$ are described as follows (Abdel-Basset et al., 2018):

$$
\begin{aligned}
& D=\left[\sum_{i=1}^{n} a_{i j}\right]_{1 \times n}=\left[a_{j}\right]_{n \times 1} \\
& R=\left[\sum_{j=1}^{n} a_{i j}\right]_{1 \times n}=\left[a_{j}\right]_{n \times 1}
\end{aligned}
$$

The horizontal axes obtain the causal diagram presented by $(D+R)$ and the vertical axes $(D-R)$, which is the degree of relation. According to experts' opinions, factor 11, namely observation and forecasting of problems, had the most significant impact. Then, information and communication systems were ranked second, and risk management ranked third. 
\begin{tabular}{l} 
AJEB \\
6,1 \\
$\mathbf{8 0}$ \\
\hline
\end{tabular}

Figure 4.

MICMAC diagram

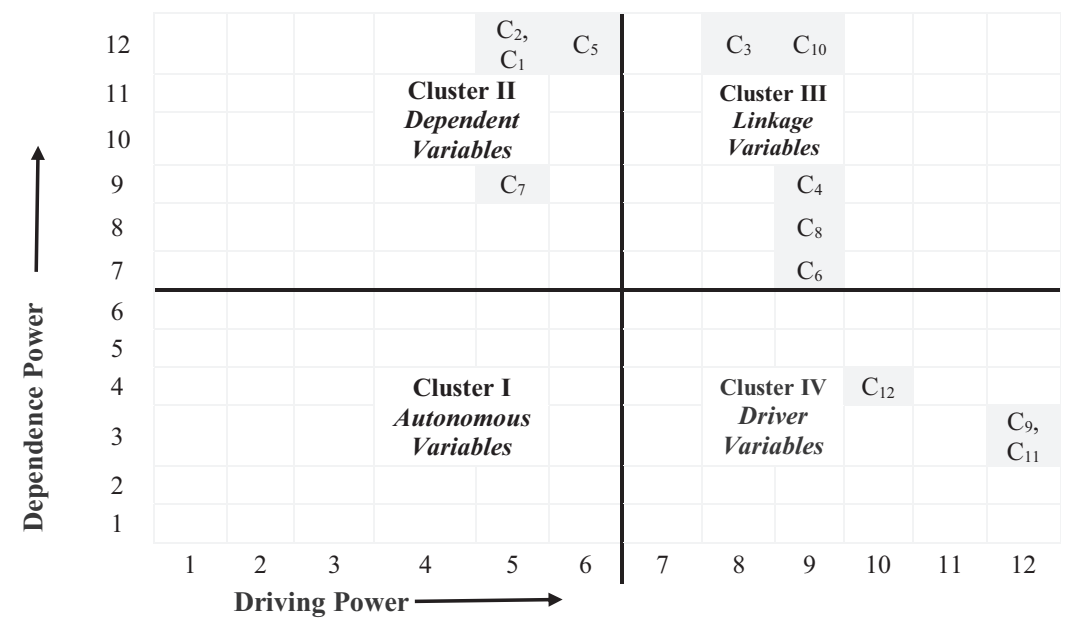

Source(s): Research Results

\begin{tabular}{|c|c|c|c|c|}
\hline Components & $D$ & $R$ & $D+R$ & $D-R$ \\
\hline 1. Observing and anticipating the problems & 4.968 & 4.099 & 9.067 & 0.869 \\
\hline 2. Information and communication systems & 4.812 & 2.292 & 7.104 & 2.520 \\
\hline 3. Risk management & 4.703 & 5.079 & 9.782 & -0.376 \\
\hline 4. Managerial features & 4.582 & 2.938 & 7.519 & 1.644 \\
\hline 5. Prevention and control of bank corruption & 4.304 & 3.289 & 7.593 & 1.015 \\
\hline 6. Financial resources management & 4.196 & 4.907 & 9.103 & -0.711 \\
\hline 7. Correct management of deferred debts & 4.048 & 3.642 & 7.690 & 0.406 \\
\hline 8. Crisis management & 3.969 & 5.018 & 8.986 & -1.049 \\
\hline 9. Liquidity management & 3.586 & 4.988 & 8.574 & -1.402 \\
\hline 10. Rumor management & 3.414 & 4.927 & 8.341 & -1.513 \\
\hline 11. The need for change and dynamism & 3.409 & 4.163 & 7.572 & -0.754 \\
\hline 12. Capital management & 2.999 & 3.646 & 6.645 & -0.648 \\
\hline
\end{tabular}

Table 9.

Results of the study on the magnitude and severity of the impact and effectiveness of banking micromanagement components
In Figure 5, each component at the highest point of the model $(D-R)$, in terms of number, affects most of the components, and each component on the left of the model $(D+R)$, in terms of severity, has the most significant impact on other factors. The results of the diagram show that information and communication systems are at the highest point of the model. After this component, two components, management features and prevention, and control of corruption are affecting a large number of factors. Also, the risk management at the end left section of the model is in the first place in terms of the severity of the impact. Financial management and monitoring and forecasting problems are in the next places.

5.2.4 Investigating the magnitude and severity of macro banking components. Table 10 presents the results of the calculations:

According to the results, the corruption of the macro-banking system can affect more components. Then the banking policies and regulations were ranked second, and the bank's connections with the government took third place.

In Figure 6, each component at the highest point of the model $(D-R)$, in terms of number, affects most of the components, and each component on the left of the model $(D+R)$, in terms of severity has the most significant impact on other factors. The results of the graph show that policy and banking laws are at the top of the model. 


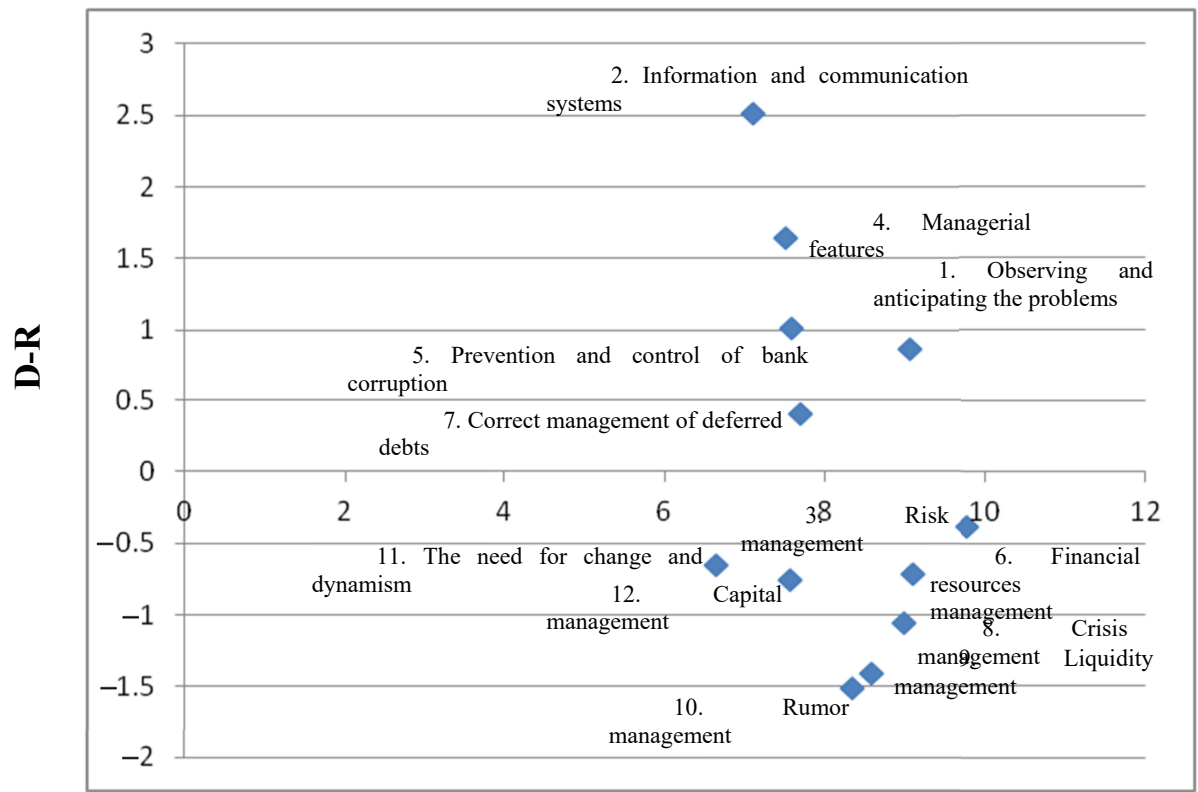

$\mathbf{D}+\mathbf{R}$
Model of
organizational
resilience

81

Corruption in the macro banking system is also at the bottom of the model, on the left, which is in the first place in terms of effectiveness. The two components of the bank's communications with the government and the corporate governance structure of the bank are also in the next place. Our findings were compared with the results of other studies in the literature (Bastanifar et al., 2019; Ebrahimi and Seif, 2015). The comparison showed that our results have a good fit with the results of other researchers, who considered the Iran banking industry as a case study for evaluating their models.

\section{Conclusions}

Organizational resilience and readiness of the banks in crisis are some of the major concerns of the banks. If banks, as one of the bases of the economy, cannot resist crises, every crisis and risk may turn into a significant dilemma in the country and lost control of the affairs of the managers. Therefore, to strengthen and develop organizational resilience in the banking

\begin{tabular}{lrrrr}
\hline Components & $D$ & $R$ & $D+R$ & $D-R$ \\
\hline 1. Corruption of the macro banking system & 11.435 & 11.731 & 23.166 & -0.296 \\
2. Policies and banking laws & 11.279 & 7.293 & 18.572 & 3.986 \\
3. The relationship of bank and government & 11.269 & 11.081 & 22.351 & 0.188 \\
4. Political preferences and changes & 10.309 & 9.684 & 19.993 & 0.626 \\
5. Bank corporate governance framework & 10.009 & 12.074 & 22.083 & -2.066 \\
6. Bank business structure & 8.517 & 10.955 & 19.473 & -2.438
\end{tabular}

Table 10. Results of the study of the magnitude and severity of the impact and the effectiveness of macro banking management components 


\section{AJEB \\ 6,1}

\section{2}

Figure 6.

The causal diagram for bank's macro components in bank organizational resilience

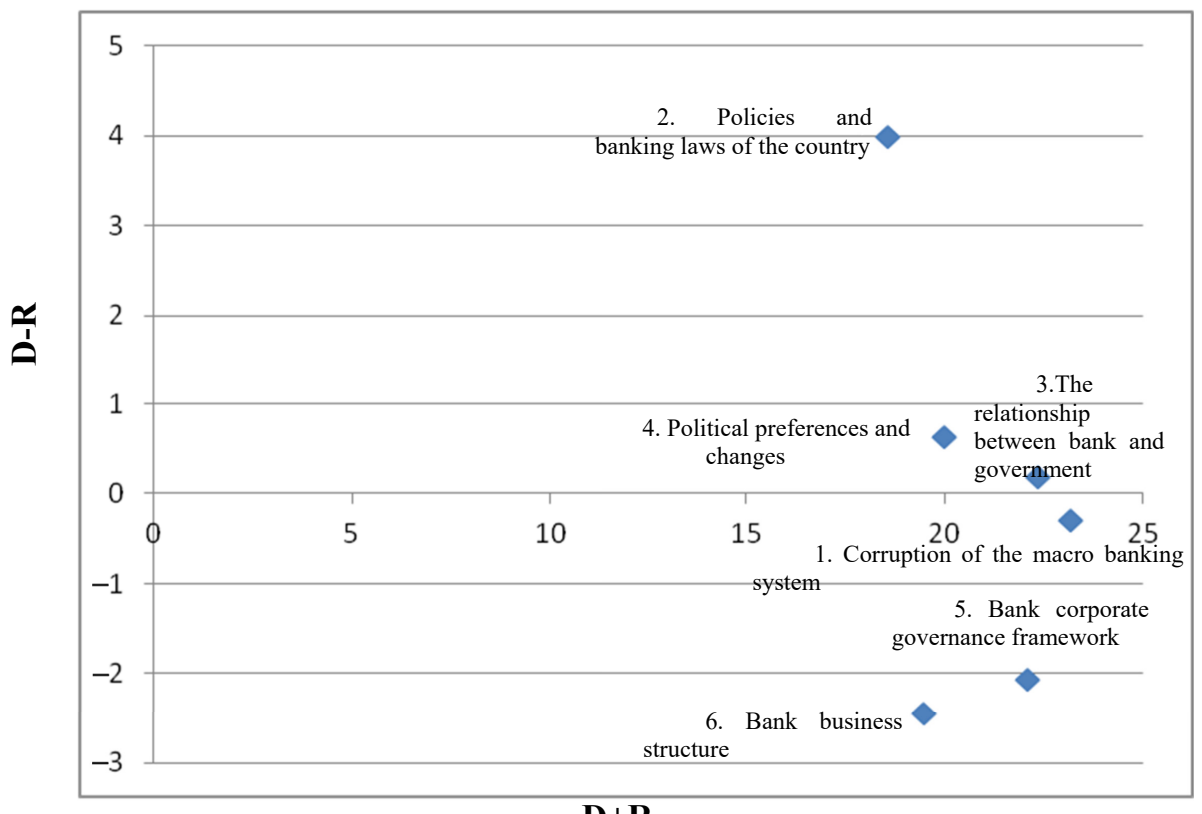

$\mathbf{D}+\mathbf{R}$

industry, there should be a model to strengthen the resilience of the whole organization and the whole industry by strengthening its dimensions and components. The present study was formed with the same view to design a model for organizational resilience in the banking industry by identifying dimensions and components of organizational resilience. Our model contained 18 concepts, 11 subcategories and 2 main categories. According to experts' opinions, observation and forecasting of problems had the most significant impact. Then, information and communication systems were ranked second, and risk management ranked third.

Therefore, based on the results, suggestions were given to the managers of the banking industry to increase increasing organizational resilience by the implementation of the following proposal. The results of the DEMATEL technique show that among the components of the macro banking dimension, the corruption of the macro banking system is a significant problem due to its high interaction with other components and its impact, which should be considered separately. Also, the component of bank communication with the government is known as a factor that can solve the main problem and should be prioritized due to its impact and high interaction with other components.

Among the components of micro bank management, the components of risk management and financial resources management are the main problem due to the high interaction with other components and their impact, which should be considered. Corruption in the macro banking system is also at the bottom of the model, on the left, which is in the first place in terms of effectiveness. The two components of the bank's communications with the government and the corporate governance structure of the bank are also in the next place. In the end, for future research, we suggest designing a quantitative index to evaluate the resilience of the banking industry based on the identified components. 


\section{References}

Abdel-Basset, M., Manogaran, G., Gamal, A. and Smarandache, F. (2018), "A hybrid approach of neutrosophic sets and DEMATEL method for developing supplier selection criteria”, Design Automation for Embedded Systems, Vol. 22 No. 3, pp. 257-278.

Alrob, M.M.A. and Jaaron, A.A. (2018), "Exploring the determinants of organizational resilience in Islamic Banks: a framework development”, International Journal of Knowledge-Based Organizations, Vol. 8 No. 4, pp. 80-98.

Anagnostopoulos, I., Noikokyris, E. and Giannopoulos, G. (2020), "A meta-crisis banking efficiency study in the MENA region", Journal of Islamic Accounting and Business Research, Vol. 11 No. 9, pp. 2087-2112.

Andersson, T., Caker, M., Tengblad, S. and Wickelgren, M. (2019), "Building traits for organizational resilience through balancing organizational structures", Scandinavian Journal of Management, Vol. 35 No. 1, pp. 36-45.

Annarelli, A. and Nonino, F. (2016), "Strategic and operational management of organizational resilience: current state of research and future directions", Omega, Vol. 62, pp. 1-18.

Bastanifar, I., Ranjbar, R. and Heidari, M.R. (2019), "Measuring the resistance of Islamic banking system (case study: Islamic Republic of Iran)”, Economic Strategy, Vol. 7 No. 27, pp. 27-63.

Berglund, T. and Mäkinen, M. (2019), "Do banks learn from financial crisis? The experience of Nordic banks", Research in International Business and Finance, Vol. 47, pp. 428-440.

Boorman, J., Fajgenbaum, J., Ferhani, H., Bhaskaran, M., Arnold, D. and Kohli, H.A. (2013), "The Centennial resilience index: measuring countries' resilience to shock", Global Journal of Emerging Market Economies, Vol. 5 No. 2, pp. 57-98.

Braun, V. and Clarke, V. (2014), "What can 'thematic analysis' offer health and wellbeing researchers?", International Journal of Qualitative Studies on Health and Well-Being, Vol. 9, 26152, doi: 10.3402/ qhw.v9.26152.

Bravo, R., Matute, J. and Pina, J.M. (2016), "Corporate identity management in the banking sector: effects on employees' identification, identity attractiveness, and job satisfaction", Service Business, Vol. 10 No. 4, pp. 687-714.

Buzgurescu, O.L.P. and Elena, N. (2020), "Bankruptcy risk prediction in assuring the financial performance of Romanian industrial companies", in Grima, S., Özen, E. and Boz, H. (Eds), Contemporary Issues in Business Economics and Finance (Contemporary Studies in Economic and Financial Analysis, Vol. 104, Emerald Publishing, pp. 19-28.

Costa, E. and Carini, C. (2016), "Northern and southern Italian social cooperatives during the economic crisis: a multiple factor analysis”, Service Business, Vol. 10 No. 2, pp. 369-392.

Dormady, N., Roa-Henriquez, A. and Rose, A. (2019), "Economic resilience of the firm: a production theory approach", International Journal of Production Economics, Vol. 208, pp. 446-460.

Dovern, J., Meier, C.P. and Vilsmeier, J. (2010), "How resilient is the German banking system to macroeconomic shocks?”, Journal of Banking and Finance, Vol. 34 No. 8, pp. 1839-1848.

Duchek, S. (2020), "Organizational resilience: a capability-based conceptualization”, Business Research, Vol. 13 No. 1, pp. 215-246.

Ebrahimi, A. and Seif, A. (2015), "The terminology and methodology of resilient banking system in the Iranian economy", Quarterly Journal of Ravand, Vol. 22 No. 71, p. 2.

Farooq, M. and Zaheer, S. (2015), “Are Islamic banks more resilient during financial panics?”, Pacific Economic Review, Vol. 20 No. 1, pp. 101-124.

Field, A.J. (2017), "The savings and loan insolvencies and the costs of financial crisis", Research in Economic History, Emerald Publishing, Vol. 33, pp. 65-113.

Fiksel, J. (2006), "Sustainability and resilience: toward a systems approach", Sustainability: Science, Practice and Policy, Vol. 2 No. 2, pp. 14-21.

\section{Model of \\ organizational resilience}


AJEB

6,1

Ismal, R. (2012), "Formulating withdrawal risk and bankruptcy risk in Islamic banking", International Journal of Islamic and Middle Eastern Finance and Management, Vol. 5 No. 1, pp. 63-77.

Kantur, D. and Say, A.I. (2015), "Measuring organizational resilience: a scale development", Journal of Business Economics and Finance, Vol. 4 No. 3, p. 456.

Kim, H., Batten, J.A. and Ryu, D. (2020), "Financial crisis, bank diversification, and financial stability: OECD countries", International Review of Economics and Finance, Vol. 65, pp. 94-104.

Lu, M.T., Tzeng, G.H., Cheng, H. and Hsu, C.C. (2015), "Exploring mobile banking services for user behavior in intention adoption: using new hybrid MADM model", Service Business, Vol. 9 No. 3 , pp. 541-565.

Markman, G.M. and Venzin, M. (2014), "Resilience: lessons from banks that have braved the economic crisis - and from those that have not", International Business Review, Vol. 23 No. 6, pp. 1096-1107.

McCarthy, I.P., Collard, M. and Johnson, M. (2017), "Adaptive organizational resilience: an evolutionary perspective”, Current Opinion in Environmental Sustainability, Vol. 28, pp. 33-40.

Naqvi, B., Rizvi, S.K.A., Uqaili, H.A. and Chaudhry, S.M. (2018), "What enables Islamic banks to contribute in global financial reintermediation?”, Pacific-Basin Finance Journal, Vol. 52, pp. 5-25.

Olfat, L. and Shahryari Nia, A. (2014), "Interpretive structural modeling of effective factors of partner selection in agile supply chain", Journal of Production and Operations Management, Vol. 5 No. 2, pp. 128-109.

Omar, O.E. (2008), "Determinants of retail bank choice in Nigeria: a focus on gender-based choice decisions", Service Business, Vol. 2 No. 3, pp. 249-265.

Pineiro-Chousa, J., Vizcaíno-González, M. and Ribeiro-Navarrete, S. (2019), "Using voting decisions to identify shocks in the financial services industry", Service Business, Vol. 13 No. 2, pp. 419-431.

Prorokowski, L. (2011), "Recovery from the current banking crisis: insights into costs and effectiveness of response regulations", Qualitative Research in Financial Markets, Vol. 3 No. 3, pp. 193-223.

Ratnovski, L. and Huang, R. (2009), "Why are Canadian banks more resilient?", International Monetary Fund, IMF Working Papers, 09, doi: 10.5089/9781451872996.001.

Rose, A. (2017), Defining and Measuring Economic Resilience from a Societal, Environmental and Security Perspective, Springer, Singapore, Imprint.

Sahebjamnia, N., Torabi, S.A. and Mansouri, S.A. (2018), "Building organizational resilience in the face of multiple disruptions", International Journal of Production Economics, Vol. 197, pp. 63-83.

Satapathy, S., Patel, S.K., Biswas, A. and Mishra, P. (2012), "Interpretive structural modeling for E-electricity utility service", Service Business, Vol. 6 No. 3, pp. 349-367.

Selmier, W.T. II (2016), "Design rules for more resilient banking systems", Policy and Society, Vol. 35 No. 3, pp. 253-267.

Shahoseini, M.A., Nazari, M. and Hashemi, M.S. (2014), "Analyzing the marketing strategies of Iranian private banks during the recession of 91 and 92", Iranian Journal of Management Sciences, Vol. 9 No. 33, pp. 125-145.

Syahkali Moradi, J. (2018), "Understanding the role of street bureaucrats in interpreting and implementing public policy”, PhD Dissertion, Teharn University (In Persian).

Yüksel, S., Dinçer, H. and Emir, Ş. (2017), "Comparing the performance of Turkish deposit banks by using DEMATEL, Grey Relational Analysis (GRA) and MOORA approaches", World Journal of Applied Economics, Vol. 3 No. 2, pp. 26-47.

\section{Corresponding author}

Mahmood Khajehpour can be contacted at: m_khajehpour@sbu.ac.ir 


\section{Appendix}
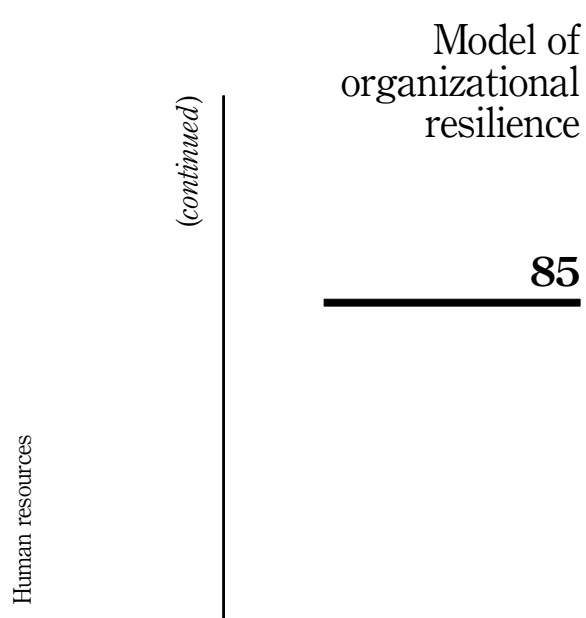

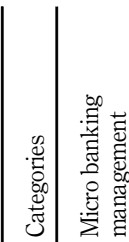
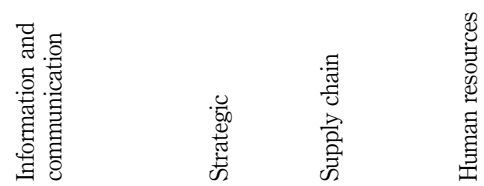

85

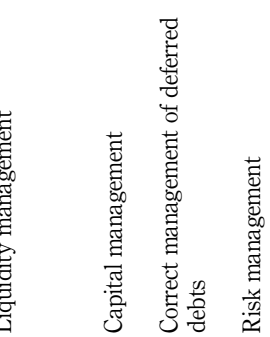

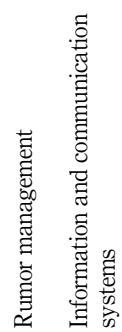

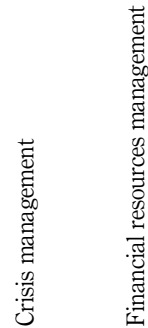

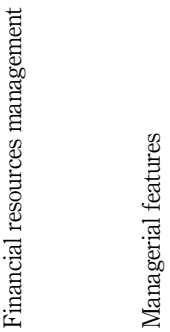

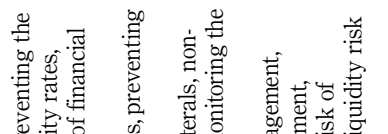

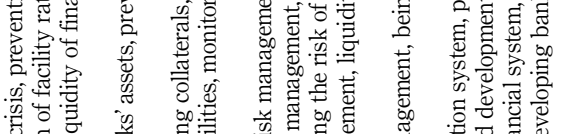

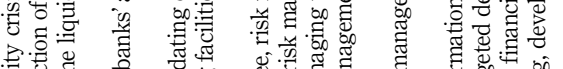

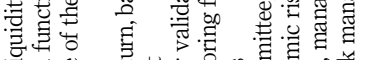

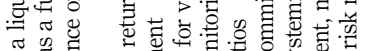

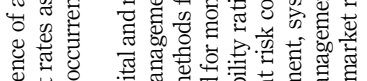

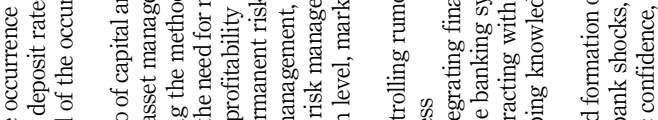

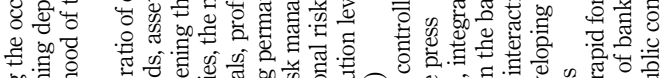

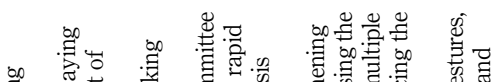

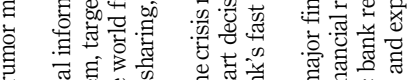

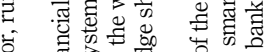

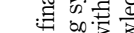

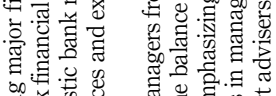

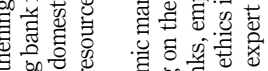

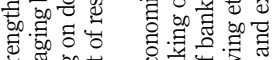

㝕 菏.

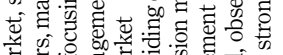

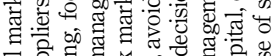
$\begin{array}{lll} & \\ 0\end{array}$

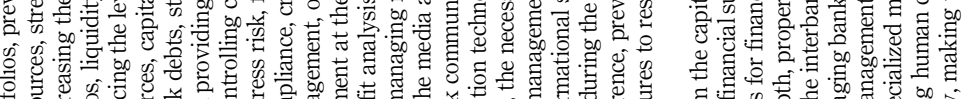

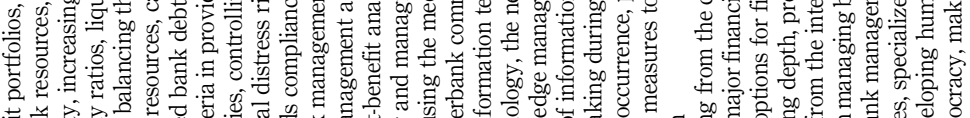
壳 o

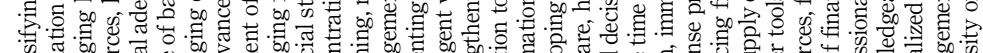

Table A1.

Thematic analysis of interviews 


\section{AJEB \\ 6,1}

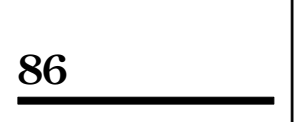

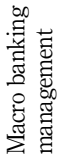

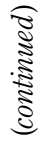

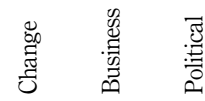

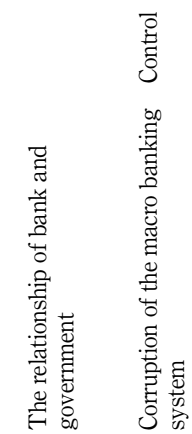

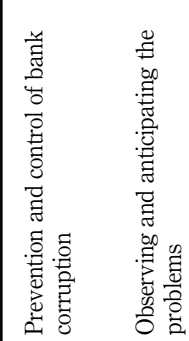

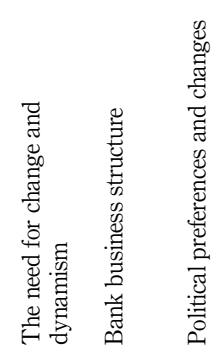

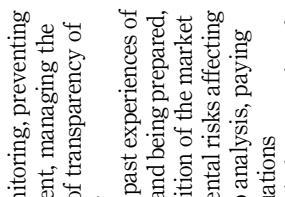

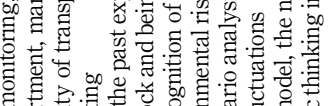

等

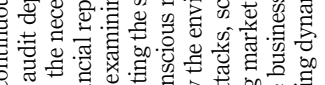

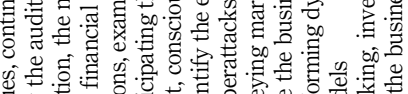

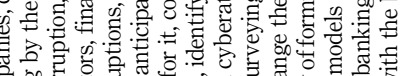

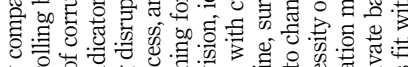

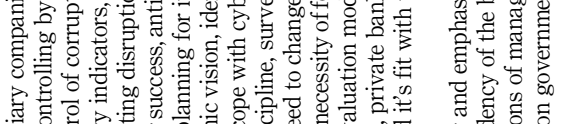

范芯 吾导导

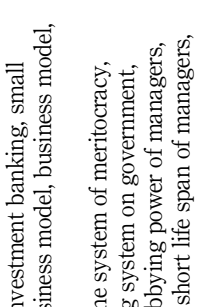

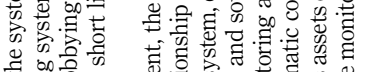

等

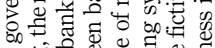

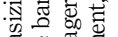

of of \&

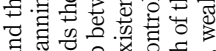

흘 굴

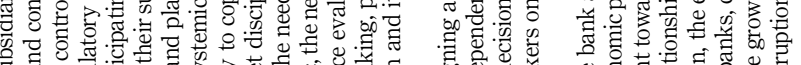

क

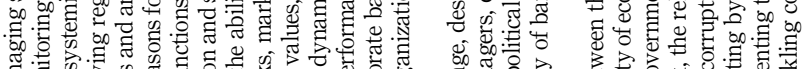

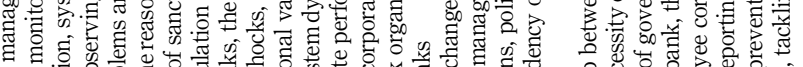

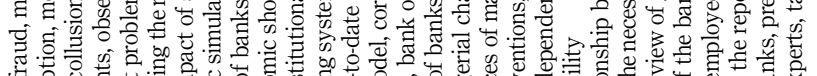

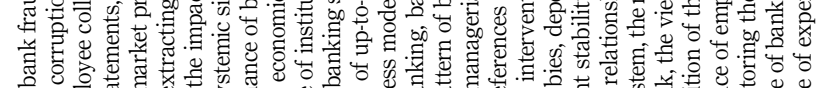

Table A1.

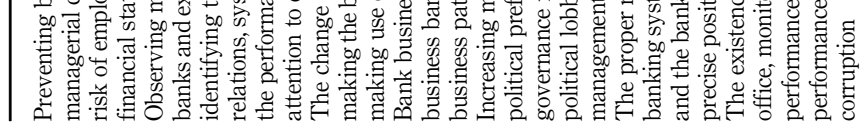


Model of organizational resilience

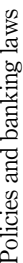

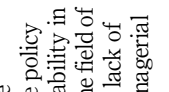

荧焉焉焉

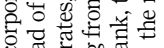

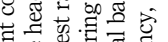

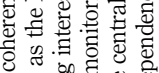

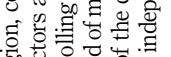

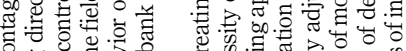

bo b 항

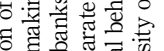

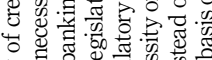

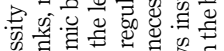

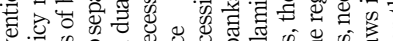

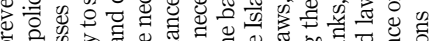

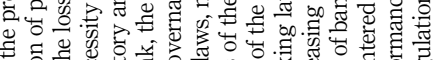

.

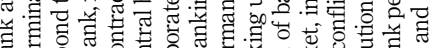

음

은

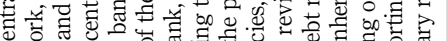

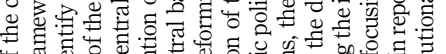

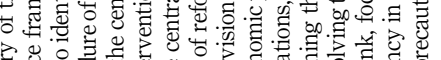

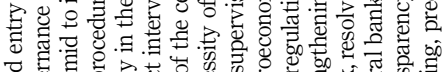

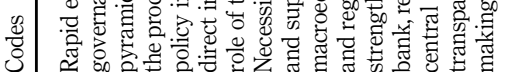

Table A1. 